\title{
FAKTOR-FAKTOR YANG MEMPENGARUHI TINGKAT KEBERHASILAN REKLAMASI TAMBANG EKSISITING BATU KAPUR PT SEMEN BATURAJA (PERSERO) TBK
}

\author{
Hisni Rahmi ${ }^{1}$, Indah Budiani ${ }^{2}$ \\ ${ }^{1}$ Teknik Pertambangan, Sekolah Tinggi Teknologi Industri Padang \\ ${ }^{2}$ Direktorat Jenderal Mineral dan Batubara, Kementerian Energi dan Sumber Daya Mineral \\ email: ${ }^{1}$ hisnirahmi@gmail.com, ${ }^{2}$ indah_budiani329@yahoo.com
}

\begin{abstract}
Abstrak
Abstrak: Tingkat keberhasilan pelaksanaan kegiatan reklamasi periode II (tahun 2017-2021) yang telah dilakukan oleh perusahaan untuk tahun 2017, 2018, 2019, dan 2020 secara berurutan diperoleh persentase sebesar 100 persen, 51,32 persen, 34,94 persen dan 23,56 persen. Berdasarkan UndangUndang Nomor 3 tahun 2020 menyatakan bahwa setiap pemilik IUP (Izin Usaha Pertambangan) atau IUPK (Izin Usaha Pertambangan Khusus) sebelum penciutan atau pengembalian wilayah IUP atau IUPK harus mencapai tingkat keberhasilan reklamasi senilai 100 persen. Penelitian ini bertujuan untuk menganalisis apa saja faktor yang mempengaruhi tingkat keberhasilan reklamasi tambang eksisting batukapur di PT Semen Baturaja (Persero) Tbk, sehingga faktor yang ditemukan menjadi acuan pelaksanaan reklamasi di sisa tahun periode II agar bisa mencapai tingkat keberhasilan yang diamanatkan dalam perundang-undangan. Penelitian dilakukan dengan melakukan survey lapangan ke lokasi penelitian dengan menggunakan instrumen penelitian berupa kuesioner yang dibagikan kepada karyawan perusahaan yang bertanggung jawab di bidang reklamasi serta melakukan pengamatan langsung di lapangan dan dari dokumen terkait. Hasil kuesioner menunjukkan bahwa faktor yang menyebabkan rendahnya pelaksanaan reklamasi oleh perusahaan adalah curah hujan yang tinggi, hama/ penyakit, dan jenis tanaman yang tidak cocok/tidak bisa tumbuh. Hasil analisis lebih lanjut berdasarkan pengamatan langsung dan dokumen terkait menunjukkan bahwa faktor utama yang mempengaruhi keberhasilan reklamasi PT Semen Baturaja (Persero) Tbk tahun 2018, 2019, dan 2020 disebabkan oleh adanya konservasi bahan galian batu kapur, sehingga menyebabkan lahan tambang yang akan direklamasi tidak dilakukan karena masih ditemukannya cadangan yang ekonomis berdasarkan hasil eksplorasi lanjutan yang dilakukandasarkan perusahaan. Hal ini menyebabkan hasil evaluasi pelaksanaan reklamasi pada aspek penatagunaan lahan menjadi rendah.
\end{abstract}

Kata kunci: faktor, tingkat keberhasilan, reklamasi, tambang batu kapur

Abstract: The success rate of the implementation of reclamation activities for period II (2017-2021) that has been carried out by the company for 2017, 2018, 2019, and 2020, respectively, obtained a percentage of 100 percent, 51.32 percent, 34.94 percent and 23.56 percent . Based on Law Number 3 of 2020, it states that every owner of IUP (Mining Business Permit) or IUPK (Special Mining Business Permit) before shrinking or returning the IUP or IUPK area must achieve a reclamation success rate of 100 percent. This study aims to analyze what are the factors that affect the success rate of reclamation of the existing limestone mines at PT Semen Baturaja (Persero) Tbk, so that the factors found become a reference for the implementation of reclamation in the remaining years of period II in order to achieve the level of success mandated in legislation. The research was conducted by conducting a field survey to the research location using a research instrument in the form of a questionnaire distributed to company employees who are responsible for reclamation as well as direct observation in the field and from related documents. The results of the questionnaire indicate that the factors that cause the company to carry out low reclamation activities are high rainfall, pests I diseases, and unsuitable plant species. The results of further analysis based on direct observation and related documents show that the main factors affecting the success of the reclamation of PT Semen Baturaja (Persero) Tbk in 2018, 2019, and 2020 are due to the conservation of limestone minerals, thus causing the mining land to be reclaimed not being carried out. because econmic reserves are still being discovered based on the results of further exploration carried out by the 
company. This causes the results of the evaluation of the implementation of reclamation in the aspect of land use management to be low.

Keywords: factors, success rate, reclamation, limestone mining

\section{PENDAHULUAN}

PT Semen Baturaja (Persero) Tbk dalam memenuhi kebutuhan baku baku pembuatan semen berupa batukapur diperoleh dengan melakukan kegiatan penambangan secara mandiri. Perusahaan sudah memiliki IUP Operasi Produksi tambang batukapur. Perusahaan memiliki kewajiban untuk menyusun rencana reklamasi dan melaksanakan kegiatan reklamasi sebagaimana tertuang dalam peraturan perundang-undangan yang berlaku di Indonesia. Perusahaan telah melaksanakan reklamasi untuk periode I (2012-2016) dan telah menyusun dan sedang menjalankan reklamasi untuk periode II (2017-2021).

Reklamasi adalah kegiatan yang dilakukan sepanjang tahapan usaha pertambangan yang bertujuan untuk menata, memulihkan dan memperbaiki kualitas lingkungan dan ekosistem yang terganggu akibat kegiatan usaha pertambangan agar dapat berfungsi kembali sesuai peruntukannya (Kamrullah, dkk, 2019). Reklamasi dapat dilakukan dalam bentuk revegetasi dan/ atau peruntukan lainnya (area pemukiman, pariwisata, sumber air, dan tempat pembudidayaan) (Rahmi, et.al. 2019). Pelaksanaan reklamasi harus terencana, sistematis dan berkelanjutan sebagai wujud pelaksanaan pertambangan yang berwawasan lingkungan (Adyano, 2017). Upaya yang dapat dilakukan untuk menjamin bahwa reklamasi berjalan sebagaimana mestinya adalah dengan melakukan evaluasi keberhasilan reklamasi (Kamrullah, dkk, 2019). Kriteria keberhasilan reklamasi tahap operasi produksi dalam bentuk revegetasi meliputi standar keberhasilan penatagunaan lahan, revegetasi, pekerjaan sipil, dan penyelesaian akhir (Kepmen ESDM Nomor 1827 K/30/MEM/2018).
Hasil evaluasi reklamasi berupa nilai persentase sejauh mana keberhasilan berhasil dilaksanakan oleh perusahaan. Evaluasi terhadap keberhasilan reklamasi bertujuan untuk menjadi acuan dalam melaksanakan reklamasi kedepannya. Artinya, jika berdasarkan hasil evaluasi persentasenya rendah, maka perlu dilakukan pelaksanaan reklamasi yang optimal di masa mendatang. Hal ini dikarenakan berdasarkan kepada UndangUndang Nomor 3 tahun 2020 menyatakan bahwa setiap pemilik IUP (Izin Usaha Pertambangan) atau IUPK (Izin Usaha Pertambangan Khusus) sebelum penciutan atau pengembalian wilayah IUP atau IUPK harus mencapai tingkat keberhasilan reklamasi senilai 100 persen. Jika perusahaan tidak melaksanakan kewajiban reklamasi sebagaimana tertuang dalam peraturan pemerintah maka akan dikenakan sanksi administratif hingga sanksi kurungan penjara 5 tahun penjara dan denda paling banyak Rp100.000.000.000,- (Undang-Undang Nomor 3 Tahun 2020)

Tingkat keberhasilan reklamasi PT Semen Baturaja (Persero) Tbk periode I yaitu tahun 2012-2016 sangat rendah. Berdasarkan data evaluasi pelaksanaan reklamasi yang diperoleh dari Dinas ESDM Provinsi Sumatera Selatan diperoleh hasil bahwa keberhasilan reklamasi pada periode I sangat rendah yaitu $7-8,91$ persen. Tingkat keberhasilan pelaksanaan kegiatan reklamasi periode II (tahun 2017-2021) yang telah dilakukan oleh perusahaan untuk tahun 2017, 2018, 2019, dan 2020 secara berurutan diperoleh persentase sebesar 100 persen, 51,32 persen, 34,94 persen dan 23,56 persen (Budiani, 2020). Tingkat keberhasilan yang dilaksanakan oleh perusahaan cenderung menurun dari tahun 2017 hingga tahun 2020. 
Berdasarkan data di atas maka jaminan reklamasi yang telah dijaminkan sebelumnya belum dapat dilakukan pencairan dikarenakan belum memenuhi batasan minimum tingkat keberhasilan yang dipersyaratkan oleh peraturan perundang-undangan yang berlaku senilai 60 persen. Jika mengacu kepada peraturan perundang-undangan yang terbaru yaitu undang-undang nomor 3 tahun 2020, maka perusahaan dapat dikenakan sanksi.

Berdasarkan hal tersebut maka penelitian ini dilakukan dengan tujuan untuk mengetahui apa faktor yang mempengaruhi tingkat keberhasilan reklamasi tambang eksisting batukapur PT Semen Baturaja (Persero) Tbk, sehingga faktor yang ditemukan menjadi acuan pelaksanaan reklamasi di sisa tahun periode II agar bisa mencapai tingkat keberhasilan yang diamanatkan dalam perundang-undangan.

\section{METODE PENELITIAN}

Penelitian dilakukan di tambang eksisting batukapur PT Semen Baturaja (Persero) Tbk di Desa Pusar, Kecamatan Baturaja Barat, Kabupaten Ogan Komering Ulu, Propinsi Sumatera Selatan (Gambar 1).

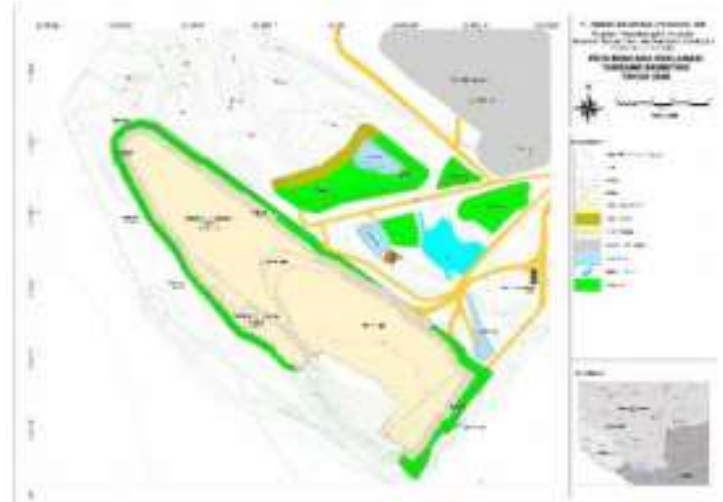

Sumber: Arsip PT Semen Baturaja (Persero) Tbk, (2017) Gambar 1. Lokasi Penelitian

Data primer didapat dengan melaksanakan pengamatan langsung ke lokasi penelitian. Data primer yang dikumpulkan berupa kondisi rona lingkungan untuk area yang belum dilakukan penambangan, kondisi lahan yang telah direklamasi oleh perusahaan, dan hasil kusioner. Instrumen penelitian berupa kuesioner dibagikan kepada karyawan perusahaan yang bertanggung jawab di bidang reklamasi. Data sekunder diperoleh dari jurnal penelitian terkait, dokumen perusahaan seperti dokumen AMDAL, studi kelayakan, rencana reklamasi, rencana pasca tambang, dan laporan pelaksanaan reklamasi perusahaan. Data sekunder adalah luasan rencana reklamasi dan luasan realisasi reklamasi tahun 2017, 2018, 2019, dan 2020 serta persentase hasil evaluasi tingkat keberhasilan reklamasi tambang eksisting batukapur perusahaan.

Analisis faktor yang mempengaruhi keberhasilan reklamasi dilakukan berdasarkan hasil kuesioner, hasil pengamatan lapangan, serta berdasarkan dokumen laporan pelaksanaan reklamasi milik perusahaan.

Konsep dasar dari penelitian ini adalah adanya IUP Operasi Produksi yang dimiliki oleh PT Semen Baturaja (Persero) Tbk. Perusahaan selain melakukan kegiatan penambangan juga berkewajiban untuk menyusun rencana reklamasi selama satu periode (5 tahun) serta melaksanakannya selama operasonal pertambangan berlangsung. Pelaksanaan reklamasi yang telah dilakukan oleh perusahaan perlu dilakukan penilaian untuk melihat sejauh mana keberhasilan pelaksanaannya. Penilaian dilakukan secara pada akhir periode pelaksanaan oleh Dinas Energi dan Sumberdaya Mineral. Perusahaan secara mandiri melakukan perhitungan keberhasilan reklamasi yang mana berkaitan dengan pencairan jaminan reklamasi setiap tahunnya. Kerangka konseptual secara ringkas disajikan pada gambar di bawah ini.

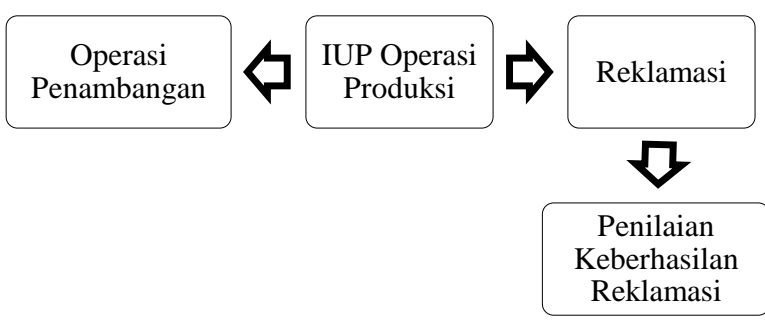

Gambar 2. Kerangka Konseptual 


\section{HASIL DAN PEMBAHASAN}

Lahan bekas tambang maupun lahan di luar bekas tambang seperti timbunan tanah penutup, timbunan bahan baku, jalan transportasi, pabrik/instalasi pengolahan/pemurnian, kantor dan perumahan, serta pelabuhan/dermaga wajib dilakukan kegiatan reklamasi (Oktabriana, 2017). Tujuan utama reklamasi adalah menjadikan kawasan yang rusak atau tak berguna menjadi lebih baik dan bermanfaat (Setyowati, dkk, 2017). Kegiatan reklamasi yang telah dilaksanakan perlu dievaluasi untuk melihat sejauh mana tingkat keberhasilannya, sehingga dapat diketahui faktor apa yang mempengaruhi rendahnya keberhasilan reklamasi yang dilakukan. Berdasarkan hal tersebut maka akan dapat dirumuskan upaya apa yang perlu dilakukan dalam mengatasi faktor penghambat reklamasi tersebut.

Berdasarkan hasil kuesioner diketahui beberapa faktor yang dapat mempengaruhi keberhasilan reklamasi dan upaya yang dilakukan dalam mengatasi faktor-faktor tersebut. Responden atau sampel sebanyak 5 orang dari 25 tenaga pelaksana reklamasi yang dimiliki oleh perusahaan. Hasil kuesioner disajikan pada tabel di bawah ini.

Tabel 1.Faktor yang Mempengaruhi Keberhasilan Reklamasi dan Cara Mengatasinya

\begin{tabular}{|l|l|l|}
\hline No. & $\begin{array}{c}\text { Kendala Yang Dihadapi } \\
\text { Dalam Reklamasi }\end{array}$ & \multicolumn{1}{|c|}{ Cara Mengatasi } \\
\hline 1. & Curah Hujan yang Tinggi & Penyaliran/Drainase \\
\hline 2 & Hama/ Penyakit & $\begin{array}{l}\text { Penyemprotan } \\
\text { Insektisida }\end{array}$ \\
\hline 3 & $\begin{array}{l}\text { Jenis tanaman yang tidak } \\
\text { cocok/tidak bisa tumbuh }\end{array}$ & $\begin{array}{l}\text { Penyulaman dan } \\
\text { Pemupukan }\end{array}$ \\
\hline
\end{tabular}

Sumber: Data primer, hasil kuesioner (2020)

Analisis untuk setiap fakor-faktor yang mempengaruhi tingkat keberhasilan reklamasi berdasarkan hasil kuesioner dan studi literatur penelitian terdahulu adalah sebagai berikut.

1. Iklim

Iklim adalah kondisi atmosfer dalam jangka waktu panjang. Lokasi penelitian berada pada wilayah yang mengalami iklim tropis. Iklim tropis memiliki dua musim, yaitu musim hujan dan musim panas. Musim yang berubah-ubah di lokasi penelitian menjadi faktor alam yang tidak dapat dikendalikan. Kegiatan reklamasi tidak dipungkiri akan dipengaruhi oleh iklim ini. Hal ini dikarenakan iklim mempengaruhi dalam kegiatan penatagunaan lahan (Tala'ohu dan Irawan, 2014). Iklim juga mempengaruhi terhadap revegetasi dan penyelesaian akhir. Pengaruh iklim terhadap penatagunaan lahan adalah mengakibatkan daya dukung dan kesuburan lahan menjadi rendah (Adyano, 2016) disebabkan dapat terjadinya erosi dan sedimentasi terutama saat musim hujan. Upaya yang dapat dilakukandalam mengatasi iklim yang berubah adalah berupa memperbanyak sump/ pond yang insite sebagai tampungan air, mencegah longsor di musim hujan, penyiraman musim kemarau, dan mengurangi beban air pencemar di hilir. Penelitian yang dilakukan oleh Dewi, dkk (2020) menunjukkan hasil bahwa 2 perusahaan di Jambi yaitu PT. Bangun Energy Indonesia dan PT. Sursarita Sukses Sejahtera terkendala karena kondisi cuaca, pada musim hujan kegiatan tidak dapat dilaksanakan.

Berdasarkan hasil penelitian diketahui bahwa iklim mempengaruhi kegiatan revegetasi dan penyelesaian akhir. Musim hujan dan musim panas mempengaruhi terhadap pertumbuhan tanaman. Musim panas akan menyebabkan pertumbuhan tanaman terganggu karena kekurangan air, sehingga menyebabkan tanaman layu. Namun dikarenakan daerah ini beriklim tropis maka walaupun musim panas tetapi masih terdapat hari hujan pada musim ini. Musim hujan menjadi salah satu kendala dalam pelaksanaan reklamasi karena musim 
hujan menyebabkan pertumbuhan tanaman yang tidak diharapkan (gulma) tumbuh dengan subur dan akan mengganggu pertumbuhan tanaman yang ditanam karena unsur hara tanah sudah diabsorpsi oleh gulma. Hal ini terlihat pada tahun 2018, dimana pada curah hujan cukup tinggi pada bulan Desember 2018 yaitu 323,5 mm. Curah hujan yang tinggi ini menyebabkan area revegetasi terdapat pertumbuhan semak yang cukup pesat yang diiringi dengan gulma. Hal ini menyebabkan penyulaman yang dilakukan yaitu sebanyak 961 batang atau sekitar $47 \%$ dari total 2.032 batang tanaman yang telah ditanam sebelumnya. Langkah yang dapat dilakukan dalam mengatasi permasalahan yang ditimbulkan oleh musim yang berubah dan tidak dapat dikontrol adalah dapat dilakukan pengendalian erosi dengan saluran air (drainase) dan penanaman cover crop (Fauzan dkk, 2020) agar unsur hara tanah tidak hilang terbawa air sehingga pertumbuhan tanaman dapat berjalan dengan baik.

2. Kondisi tanah dan pemilihan tanaman

Kegiatan penambangan akan menyebabkan kerusakan terhadap komposisi tanah. Kerusakan sifat fisika dan kimia tanah diakibatkan oleh penggalian top soil untuk mencapai lapisan bahan tambang yang lebih dalam sehingga mengubah topografi dan komposisi tanah permukaan (Setyowati, dkk, 2017). Kerusakan pada tanah menyebabkan tidak dapat tumbuhnya tanaman yang ditanam secara baik sehingga menyebebkan rendahnya tingkat keberhasilan reklamasi yang dilakukan. Hal ini sejalan dengan penelitian yang telah dilakukan oleh Hendri dan Purnama (2016) dimana hasil penelitiannya menunjukkan bahwa kriteria kesuburan tanah di lokasi tambang batubara muda di Kabupaten Muaro Jambi dan Batanghari tergolong rendah hingga sangat rendah yang mempengaruhi terhadap keberhasilan reklamasi di lokasi tersebut. Upaya yang dapat dilakukan dalam mengatasi permasalahan top soil tipis dan tingkat kesuburan yang rendah dengan melakukan penyelamatan topsoil, pemberian bahan organik/ pupuk kompos, penggunaan TKKS (tandan kosong kelapa sawit), mengambil tanah subur daerah sekitar, dan pola penanaman dengan cara potting.

Keberhasilan reklamasi selain dipengaruhi oleh kondisi tanah juga sangat dipengaruhi oleh pemilihan tanaman (Setyowati, dkk, 2017). Pemilihan tanaman untuk revegetasi lahan bekas tambang harus memperhatikan riwayat penggunaan lahan. Kandungan sisa bahan tambang dapat mempengaruhi pertumbuhan tumbuhan tertentu. Oleh karena itu perlu dilakukan identifikasi awal terkait kondisi lahan serta karateristik tanah lahan bekas tambang sebelum dilakukan reklamasi.

Kriteria pemilihan jenis pohon untuk lahan bekas tambang dapat dilihat dari: (1) jenis lokal pioner, (2) cepat tumbuh tetapi tidak memerlukan biaya yang tinggi, (3) menghasilkan serasah yang banyak dan mudah terdekomposisi, (4) sistim perakaran yang baik dan mampu bersimbiosis atau berhubungan timbal balik dengan mikroba tertentu, (5) merangsang datangnya vector pembawa biji, (6) mudah dan murah dalam perbanyakan, penanaman dan pemeliharaan. Keberhasilan revegetasi bergantung pada beberapa hal seperti persiapan penanaman, pemeliharaan tanaman serta pemantauan tanaman (Setyowati, 
dkk, 2017). Upaya yang dapat dilakukan dalam mengatasi permasalahan lahan selektif terkait jenis tanaman adalah covercrop yang beradaptasi kondisi kesuburan tanah, jenis tanaman utama yang cepat tumbuh dan lokal, serta sistem tanaman shading.

Berdasarkan hasil penelitian diketahui bahwa pada tahun 2018 terjadi kegagalan tumbuh pada bagian tenggara IUP dengan jenis tanaman karet. Hasil penelitian mengindikasikan bahwa kegagalan reklamasi disebabkan oleh tidak cocoknya tanaman yang ditanam terhadap kondisi tanah di lahan bekas penambangan. Oleh karena itu pihak perusahaan mengganti tanaman yang akan ditanam dengan tanaman sengon dan cemara pada lokasi tersebut.

3. Serangan hama

Serangan hama antara lain ulat, serangga ataupun babi. Hama serangga dan ulat biasanya akan memakan dedaunan dari tanaman yang ada. Hama babi biasanya menjadikan tanaman yang ditanam sebagai bahan pangan mereka. Hal ini menyebabkan keberadaan hama akan menghalangi pertumbuhan dari tanaman yang telah ditanam. Solusi yang dapat digunakan dalam mengatasi hama seperti ulat dan serangga adalah melakukan penyemprotan insektisida pada tanaman. Hama babi hutan diatasi dengan melakukan pengalihan pada area lain dengan pancingan makanan.

4. Tenaga pelaksana reklamasi

Keberhasilan

pelaksanaan reklamasi tidak terlepas dari sumber daya manusia yang melaksanakan kegiatan tersebut. Pelaksana reklamasi memiliki tanggungjawab pada seluruh tahapan kegiatan reklamasi mulai dari kegiatan penataan lahan, penebaran tanah zona pengakaran, revegetasi, pemeliharaan, dan pemantauan. Peran dari tenaga pelaksana reklamasi ini di mulai dari perencanaan reklamasi, penentuan metode reklamasi yang akan dilakukan, pemilihan jenis tanaman yang sesuai pada area reklamasi, pembuatan desain area timbunan, penentuan kestabilan lereng, perencanaan biaya reklamasi, hingga pada pelaksanaan dan perawatannya. Hal ini menyebabkan dibutuhkannya tenaga ahli yang kompeten di dalam perencanaan dan pelaksanaan reklamasi agar kegiatan reklamasi berjalan sesuai dengan yang diharapkan dan rencana yang telah disusun. Hal ini agar tidak terjadi seperti halnya di PT Madhani Talatah Nusantara tidak berhasil dalam bidang penutupan tajuk dikarenakan tidak adanya perencanaan, tajuk dibiarkan sendiri tumbuh berupa semak belukar, dan terjadinya erosi dan sedimentasi (Putri, dkk, 2017). Hal serupa juga terjadi di Jambi yaitu PT. Bangun Energy Indonesia dan PT. Sursarita Sukses Sejahtera yang melaksanakan penatagunaan lahan hanya karena memenuhi kewajiban tanpa perencanaan yang matang sehingga menyebabkan rendahnya tingkat keberhasian reklamasi yaitu PT. Bangun Energy Indonesia memiliki tingkat keberhasilan 52,98 persen dan PT. Sursarita Sukses Sejahtera dengan tingkat keberhasilan 9,6 persen (Dewi, dkk, 2020).

Berdasarkan penelitian yang telah dilakukan diperoleh data bahwa kegiatan pengontrolan terhadap tumbuhnya tanaman setiap hari dilakukan oleh tenaga pelaksana reklamasi. Oleh karena itu dari segi revegetasi dalamhal pertumbuhan tanaman berlangsung baik, hanya saja luasan lahan yang ditanam tidak sesuai dengan rencana yang telah disusun. Kegiatan perawatan juga 
telah dilakukan dengan baik oleh tenaga pelaksana reklamasi melalui pemupukan dengan NPK pada tanaman. Kegiatan penyulaman juga dilakukan dengan baik dibuktikan dengan melaksanakan penyulaman sejumlah tanaman yang mati, dimana pada tahun 2018 sebanyak 961 batang dan tahun 2019 sebanyak 228 batang.

5. Lahan tambang yang masih aktif

Kegiatan reklamasi merupakan upaya yang dapat dilakukan oleh pelaku usaha pertambangan untuk menjaga kestabilan dan pengelolaan lingkungan, sehingga dapat menekan dampak yang dapat ditimbulkan dari kegiatan penambangan yang dilakukan. Kegiatan reklamasi dilakukan pada area-area yang terdampak langsung dari kegiatan penambangan seperti area tambang itu sendiri, area timbunan tanah penutup dan/ atau batuan penutup, area fasilitas infrastruktur, kolam pengendapan lumpur, area pengolahan, jalan, dan sebagainya.

Kegiatan reklamasi akan dilakukan sesuai dengan rencana yang telah dibuat terhadap area yang terdampak tersebut. Kegiatan reklamasi yang dilaksanakan pada pelaksanaannya terkadang tidak sesuai dengan jadwal yang direncanakan sebab pada area yang rencananya akan direklamasi tersebut masih ada kegiatan yang dilakukan atau area tersebut dapat dikatakan sebagai area tambang aktif. Berdasarkan penelitian yang telah dilakukan diketahui bahwa pada Tahun 2017 tidak ada rencana pembukaan lahan tapi realisasinya dilakukan bukaan lahan sebesar 1,2 ha. Proses pembukaan lahan dilakukan karena tingkat kebutuhan batu kapur yang meningkat, sehingga perlu dilakukan percepatan pembukaan lahan di area barat pit (pelebaran) karena area bottom pit sulit dilakukan terkendala cuaca yang tidak menentu dan kuantitas pompa yang kurang. Sementara pada tahun 2018 direncanakan untuk melakukan penimbunan tanah penutup di area bekas tambang (inpit dump) pada area seluas 3,48 hektar dan penimbunan di luar pit penambangan (outpit dump) pada area seluas 2,79 hektar. Realisasi pelaksanaan reklamasi di lapangan dilaksanakan pada outpit dump atau area Disposal 2 sesuai dengan luasan yang direncanakan. Pelaksanaan reklamasi pada area inpit dump belum dapat dilaksanakan karena pada area tersebut masih dilakukan kegiatan penambangan (tambang aktif). hal ini karena rencana bukaan lahan tahun 2018 seluas 41 ha dengan realisasi bukaan lahan 4,52 ha. Proses pembukaan lahan dilakukan karena tingkat kebutuhan batu kapur yang meningkat, sehingga perlu dilakukan percepatan pembukaan lahan sekaligus optimalisasi penambangan di area barat pit hingga mencapai batas pit limit atau Life Of Mine (LOM). Hal yang sama terjadi pada tahun 2019, rencana reklamasi yang direncanakan ialah pada area bekas tambang seluas 1,66 hektar dan lahan bekas timbunan (Disposal 3) seluas 3,5 hektar. Sementara karena area tambang tersebut masih aktif digunakan, sehingga realisasinya hanya seluas 0,6 hektar untuk area bekas tambang dan 0,85 hektar untuk lahan bekas disposal. Rencana reklamasi pada tahun 2020 adalah 2,78 ha pada lahan disposal dan 4,7 ha. Rencana bukaan lahan tahun 2019 seluas 11,3 ha dan tahun 2020 seluas 13,80 ha, tetapi realisasinya tidak ada bukaan lahan. Pembukaan lahan di tambang existing sudah maksimal dilakukan pada tahun 2018 hingga batas pit limit atau batas LOM-nya, sehingga tidak lagi dilakukan pembukaan lahan pada 
tahun 2020 maupun tahun-tahun selanjutnya. Hal ini berdampak besar kepada persentase keberhasilan reklamasi yang dilakukan oleh PT Semen Baturaja (Persero) Tbk. Hal ini terjadi dikarenakan adanya kegiatan konservasi bahan galian berupa batu kapur berdasarkan hasil eksplorasi lanjutan yang dilakukan perusahaan. Oleh karena itu perusahaan masih melakukan Kegiatan penambangan pada lokasi yang seharusnya direklamasi karena cadangannya masih ekonomis untuk ditambang. Hal ini menyebabkan evaluasi pelaksanaan reklamasi pada aspek penatagunaan lahan menjadi rendah.

Tingkat keberhasilan reklamasi pada tahun 2018, 2019, dan 2020 menunjukkan persentase tingkat keberhasilan secara berututan senilai 51,32 persen, 34,94 persen, dan 23,56 persen. Berdasarkan hasil kuesioner dan pengamatan yang dilakukan di lapangan diperoleh faktorfaktor yang mempengaruhi rendahnya keberhasilan reklamasi adalah iklim, kondisi tanah dan pemilihan tanaman, serangan hama, tenaga reklamasi, dan lahan tambang yang masih aktif. Berdasarkan undang-undang nomor 3 tahun 2020 bahwa sebelum penciutan atau pengembalian WIUP atau WIUPK harus mencapai tingkat keberhasilan reklamasi senilai 100 persen. Oleh karena itu perusahaan wajib melaksanakan komitmennya untuk mereklamasi lahan sesuai dengan rencana reklamasi yang telah disusun dan disetujui. Perusahaan dapat melakukan upaya peningkatan pelaksanaan reklamasi dengan melaksanakan teknologi tepat guna, pemilihan bibit tanaman, dan lainnya agar hasil evaluasi pelaksanaan reklamasi mencapai hasil yang disyaratkan dalam peraturan yang berlaku.

Kewajiban reklamasi yang dilakukan oleh perusahaan tidak hanya sebatas menghijaukan lahan bekas penambangan namun juga ada upaya untuk mempertahankan dan melestarikan keanekaragaman hayati flora dan faunanya. Perspektif nilai tambah (added value) pada reklamasi tambang memberikan konstribusi dalam mencapai tujuan pembangunan berkelanjutan (Sustainable Development Goals). Reklamasi berkelanjutan tentunya tidak hanya faktor teknis semata dan perlu mempertimbangkan aspek sosial dan ekonomi lokal dalam keberlanjutan reklamasi ke tahap pascatambang. Hal ini diharapkan agar perusahaan ikut serta dalam mewujudkan pembangunan berkelanjutan, karena dapat diwujudkan jika berdasarkan pada tiga pilar lingkungan berkelanjutan yaitu ekonomi, sosial, dan lingkungan (Juniah, 2018). Hal tersebut juga berguna agar keberhasilan reklamasi dapat dicapai. Ketercapaian kegiatan reklamasi ini berdampak terhadap lingkungan yang tertata dengan baik dan juga memberikan manfaat ke perusahaan dalam mencairkan dana jaminan reklamasi. Jika hasil evaluasi pelaksanaan reklamasi pada periode II tahun 2017-2021 di bawah nilai yang disyaratkan oleh peraturan perundang-undangan, maka perusahaan nanti wajib mengusulkan pihak ketiga yang memiliki Izin Usaha Jasa Pertambangan di bidang Pascatambang dan Reklamasi kepada Menteri melalui Direktur Jenderal, gubernur, atau bupati/walikota sesuai dengan kewenangannya, dan kemudian akan dilakukan evaluasi untuk menetapkan pihak ketiga. Hal ini sebagaimana diamanatkan pada pasal 61 Permen ESDM no. 7 tahun 2014, dimana jika setelah 2 (dua) tahun periode penilaian berturutturut, pelaksanaan reklamasi benlum mencapai keberhasilan 60 persen.

Berdasarkan analisis yang dilakukan diperoleh faktor yang menjadi kendala utama dalam pelaksanaan reklamasi tambang eksisiting batukapur PT Semen Baturaja (Persero) Tbk adalah luasan lahan yang direncanakan untuk direklamasi masih dilakukannya kegiatan 
penambangan. Kegiatan pertambangan yang dilakukan pada lahan yang sudah direncanakan untuk direklamasi dilakukan karena masih terdapatnya cadangan yang dapat ditambang berdasarkan hasil eksplorasi lanjutan. Hal ini dilakukan dalam rangka konservasi bahan galian dimana mengoptimalkan manfaat dari potensi bahan galian karena dalam upaya konservasi tidak menghendaki adanya potensi bahan galian yang tidak dimanfaatkan (Suprapto, 2008). Berdasarkan hal ini, artinya bahwa luasan rencana reklamasi PT Semen Baturaja (Persero) Tbk berubah pada luasan lahan bekas tambang yang akan direklamasi.

Peraturan Pemerintah (PP) Nomor 78 Tahun 2010 tentang reklamasi dan pascatambang menyebutkan bahwa perusahaan wajib melakukan perubahan rencana reklamasi yang telah disetujui apabila terjadi perubahan atas sistem dan metode penambangan yang telah disetujui, kapasitas produksi, umur tambang, tata guna lahan, dan dokumen lingkungan hidup yang telah disetujui oleh instansi yang berwenang sesuai dengan ketentuan peraturan perundang-undangan di bidang perlindungan dan pengelolaan lingkungan. Berdasarkan kepada kondisi di lokasi penelitian diketahui bahwa ada perubahan atas tata guna lahan berupa perubahan tata guna lahan bekas tambang yang direncanakan untuk direklamasi namun tidak direalisasikan disebabkan masih adanya cadangan. Oleh karena itu, mengacu kepada PP nomor 78 tahun 2010 maka PT Semen Baturaja (Persero) Tbk wajib melakukan perubahan terhadap rencana reklamasi yang telah disetujui. Perubahan yang disampaikan oleh perusahaan memuat mengenai alasan perubahan dokumen rencana reklamasi yang disebabkan oleh adanya perubahan tataguna lahan yang disebabkan oleh masih ditemukannya cadangan yang ekonomis setelah dilakukannya eksplorasi lanjutan. Perubahan dokumen rencana reklamasi tambang batu kapur PT Semen Baturaja (Persero) Tbk memuat mengenai luasan rencana pembukaan lahan, luasan rencana reklamasi, biaya reklamasi berdasarkan perubahan tata guna lahan yang terjadi. Perubahan rencana reklamasi tersebut diajukan dalam jangka waktu paling lambat 180 (seratus delapan puluh) hari kalender sebelum pelaksanaan reklamasi tahun berikutnya kepada Menteri, gubernur, atau bupati/walikota sesuai kewenangannya.

\section{KESIMPULAN}

1. Faktor yang mempengaruhi keberhasilan reklamasi berdasarkan hasil kuesioner menunjukkan bahwa faktor yang menyebabkan rendahnya pelaksanaan reklamasi oleh perusahaan adalah curah hujan yang tinggi, hama/ penyakit, dan jenis tanaman yang tidak cocok/tidak bisa tumbuh.

2. Faktor utama yang mempengaruhi keberhasilan reklamasi PT Semen Baturaja (Persero) Tbk tahun 2018, 2019, dan 2020 disebabkan oleh adanya konservasi bahan galian batu kapur, sehingga menyebabkan lahan tambang yang akan direklamasi tidak dilakukan karena masih ditemukannya cadangan yang ekonmis berdasarkan hasil eksplorasi lanjutan yang dilakukan perusahaan, sehingga menyebabkan evaluasi pelaksanaan reklamasi pada aspek penatagunaan lahan menjadi rendah.

\section{DAFTAR PUSTAKA}

Adnyano A. A. I. A. Penilaian Tingkat Keberhasilan Reklamasi (Permen ESDM No. 7 Tahun 2014) Lahan Bekas Tambang Pit 1 PT Pipit Mutiara Jaya di Kabupaten Tana Tidung Kalimantan Utara. Promine Journal, 4 (1): 34 - 39. (2016)

Budiani, I. Evaluasi Tingkat Keberhasilan Kegiatan Reklamasi Tambang Eksisting Batu Kapur PT Semen Baturaja (Persero) Tbk. Tesis tidak dipublikasikan. Magister Teknik 
Pertambangan Fakultas Teknik niversitas Sriwijaya. (2020)

Dewi, A. S., Ashyar, R., Helmi. Analisis Implementasi Regulasi Reklamasi Pertambangan Batubara Berdasarkan Permen ESDM No. 07 Tahun 2014 di Kabupaten Batang Hari Provinsi Jambi. Jurnal Pembangunan Berkelanjutan, 3 (1): 66-72. (2020)

Fauzan, M., Yusuf, M., Iskandar, H. Tingkat Keberhasilan Kegiatan Reklamasi Area Disposal Meranjat Pt. Bumi Merapi Energi. Jurnal Pertambangan, 4 (1): 59-66. (2020)

Hendri, J., dan Purnama, H., 2016. Karakteristik Kimia Tanah Lahan Reklamasi Tambang Batubara di Provinsi Jambi. Prosiding Seminar Nasional Lahan Suboptimal 2016, Palembang 20-21 Oktober 2016.

Juniah, R. Harmonization of Green Open Space as Carbon Assimilator for Sustainable Environment of Transportation Sector and Steam Power Plant. Sriwijaya Journal of Environment, 3(1):43-46. (2018)

Kamrullah M, Hemon, M. T., dan Syaf, H. Evaluasi Pelaksanaan Reklamasi Lahan Penambangan Bijih Nikel PT. Wijaya Inti Nusantara di Kecamatan Laeya, Konawe Selatan. Jurnal Perencanaan Wilayah, 4 (1): 1-12. (2019)

Keputusan Menteri Energi dan Sumber daya Mineral Nomor 1827 K/30/MEM/2018. Pedoman Pelaksanaan Kaidah Teknik Pertambangan yang Baik

Oktabriana, G dan Syofiani, R. Pemanfaatan Legum Cover Crop Untuk Memperbaiki Sifat Kimia Tanah Pada Lahan Bekas Tambang
Emas Di Kabupaten Sijunjung. Jurnal Agrosains dan Teknologi, 2(2). (2017)

Peraturan Menteri Energi dan Sumber Daya Mineral Nomor 7 Tahun 2014. Pelaksanaan Reklamasi dan Pasca Tambang Pada Kegiatan Usaha Pertambangan Mineral dan Batubara. (2014)

PT Semen Baturaja (Persero) Tbk. Dokumen Rencana Reklamasi PT Semen Baturaja (Persero) Tbk Periode 2017-2021. Kabupaten Ogan Komering Ulu. (2017).

Putri, A., Widayati, S., Usman, D. N. Kajian Penilaian Kebehasilan Reklamasi Lahan Bekas Penambangan Batubara di PT Madhani Talatan Nusantar Desa Rantau Nangka, Kecamatan Sungai Pinang, Kabupaten Banjar, Provinsi Kalimantan Selatan. Prosiding Teknik Pertambangan,3 (2). (2020)

Rahmi, H. Susetyo, D., Juniah, R. Utilization Study of Void Mine For Sustainable Environment of The Limestone Mining Sector at PT Semen Baturaja (Persero) Tbk. Indonesian Journal of Environmental Management and Sustainability. 3 (2): 54-59. (2019)

Setyowati, R. D. N., Amala, N. A., Aini, N. N. U. Studi Pemilihan Tanaman Revegetasi Untuk Keberhasilan Reklamasi Lahan Bekas Tambang. Al-Ard: Jurnal Teknik Lingkungan. 3 (1):14-20. (2020)

Suprapto, S.J. Tinjauan Reklamasi Lahan Bekas Tambang dan Aspek Konservasi Bahan Galian. Buletin Sumber Daya Geologi Vol 3 No 1 Tahun 2008. Badan Geologi 
Kementrian ESDM - Bandung. (2008)

Tala'ohu SH, Irawan. Reklamasi Lahan

Pasca Penambangan Batubara.

Prosiding Pembahasan Penelitian

Tanah dan Agroklimat. Pusat Penelitian Tanah dan Agroklimat. Bogor. hlm 187-213. (2014)

Undang-Undang Republik Indonesia No. 3 Tahun 2020. Tentang perubahan atas Undang-Undang Republik Indonesia No. 4 Tahun 2009 tentang Pertambangan Mineral dan Batubara. (2020) 